\title{
"Ne pas accepter les parois": Claudel's Call in America for a new form of Drama and Music
}

\author{
M. Kathleen Madigan \\ Rockhurst University, Kansas City
}

$\mathrm{O}_{\mathrm{n}}$ the occasion of the publication of The Book of Christopher Columbus at the Newhaven Yale University Press, Paul Claudel was invited to give a lecture in February, 1930 (Claudel $1965,1422)^{1}$. If there is anything I have come to appreciate in my reading of this lecture on Drama and Music ("Le Drame et la Musique") and related to that, Le Livre de Christophe Colomb (first performed in 1930) and Claudel's correspondence with his collaborator the composer Darius Milhaud, it is the quest for creativity through breadth, fusion and innovation which breaks down generic, geographic, temporal, national and, to some extent, religious barriers.

In his Yale lecture, Claudel begins by stating why he must move beyond the type of music and drama currently popular, namely Wagner's opera. One can only imagine the laughter he must have provoked at comments such as the following (referring to Tristan):

Quand un monsieur et une dame se sont dit pendant deux actes: Je t'aime - tu m'aimes, le spectateur trouve que c'est suffisant, et quand il s'aperçoit au troisième acte que ça va recommencer, il est saisi d'un véritable désespoir et d'une envie de fuir que tous les solos de clarinette ne suffisent pas à apaiser. (Claudel 1930, 10)

And before I give the impression that Claudel comes across as arrogant or nationalistic in this lecture, I should mention that he also states "Je ne suis nullement musicien" (Claudel 1930, 12), which his 


\section{Kathleen Madigan}

collaborators would qualify by stating that he actually had a marvelous gift for explaining the atmosphere of a scene so as to facilitate the composing of music. ${ }^{2}$ In spite of his critique, he calls Wagner "ce grand homme" and his work "formidable". In addition, he, like the French composer Darius Milhaud ${ }^{3}$ rejected purely French art and music (Kelly 7). On the contrary, he speaks about the use of music in Japan (at the Imperial Theatre) as a model to elicit emotion by a simple rhythm rather than a whole orchestra, for instance one man beating a drum before a grand event (Claudel 1930, 22); thus, instead of underlining words, music can precede and provoke them (Claudel 1930, 25). Claudel ends his lecture by focusing on Christophe Colomb, which was to be performed a little over a month later in Berlin, with the music of Milhaud, the first edition of which had just appeared with the drawings of Jean Charlot, a French artist of Aztec heritage who had worked in Mexico.

When Claudel was first asked to write this work, suggested by Max Reinhardt, he hesitated, since he had only written imaginative works rather than historical ones. At first, for that reason, he was not taken at all by the idea, though I have not found any evidence that he was as intimidated as he would later be by the request to write about Joan of Arc (Jeanne d'Arc au Bûcher, 1934$35)$; this could be because not so many of the exact words of this historical figure had been recorded as in Joan's trial proceedings and because Columbus was not as highly extolled as the saint, though apparently there had been a movement to canonize Columbus in the nineteenth century. It was not long, however, before an idea of how to proceed with Christopher Columbus came to him, which enabled him to write almost at once ${ }^{4}$. Reinhardt never did come through in the end with arrangements for the opera, in spite of frequent attempts on Claudel's part to communicate with him; Reinhardt's silence maddened him, and when Milhaud finally arranged for the opera to be performed at the Staatsoper in Berlin, Claudel mused about "la tête qu'il [Reinhardt] va faire" (Claudel 1961, 108) when he learned about its success. Claudel and Milhaud almost had to climb over walls literally to get the opera performed. 
In any case, in his lecture, Claudel speaks about the role of music in this drama as completely new, that is, not simply something that would support the drama, but rather that of a true actor ("un acteur véritable"). He quotes Pascal as saying that continual eloquence bores, and Claudel in turn replies that continual poetry or music bores, and adds that gradations must be created between reality and the lyrical state (Claudel 1930, 30), which, he explains, is why he and Milhaud wanted to show how the soul arrives little by little at the state of music,

[...] comment la phrase jaillit du rythme, la flamme du feu, la mélodie de la parole, la poésie de la réalité la plus grossière, et comment tous les moyens de l'expression sonore depuis le discours, le dialogue et le débat soutenus par de simples batteries, jusqu'à l'éruption de toutes les richesses vocales, lyriques et orchestrales, se réunissent en un seul torrent à la fois divers et ininterrompu. (Claudel 1965, 153)

Diversity was certainly a hallmark of this work, in addition to innovation.

Claudel ends his talk by stating that a new attempt in the production might interest his audience, which is born of the desire to "ne pas accepter de parois", to reject walls or ready-made shows, and instead to have our music and décor surge from within and to paint the waves of these on the panels of the magical box where we have been closed in for a moment (Claudel 1930: 35). He then makes the refreshing suggestion to consider cinema. The décor could be used as a simple square or frame behind which a path is open to dream, memory and imagination (Claudel 1930: 36). The lecturer finishes by calling on America to help artists find the formula for an alliance with cinema and music. Particularly rejuvenating in this lecture is that call to transcend boundaries for the purpose of discovery and creativity. Claudel was no less an explorer in the domain of the arts than the geographical one he sought to portray. 


\section{Kathleen Madigan}

The breadth included in this attempt at what he called "total theatre", poetry, music, art, dance and then film, is remarkable. While Christophe Colomb has been called an opera, it also has elements of an oratorio (Kelly 99). A fusion of the old and the new, it contains both elements of classical drama in the use of the chorus and protagonist (Kelly 104-105) and of the experimental in employing film to portray the inner states of his characters, symbolism and different time periods, such as the young Christopher Columbus reading about Marco Polo or the symbolism of the dove as sign of the Holy Spirit (Kelly 41). Once again, we see Claudel trying to scale the walls of appearance by delving into inner states with film:

Le public ne regarde pas seulement les acteurs. Il a besoin de savoir ce qui se passe dans leur cour et dans leur tête; de connaître ces mystérieux avertissements venus d'ailleurs que leur suggère la Destinée ou la Providence. C'est à quoi sert l'écran qui forme le fond de la scène... C'est un paysage spirituel qui remplace l'ancien site matériel. Sur cette toile se peignent...toutes sortes d'images...dans le passé, dans le présent, dans le possible et dans le rêve. (Claudel Théâtre, tome II, 1491, quoted in Autrand 317)

Film thus emphasized the action from a different angle or context, or at times blurred images to indicate the thoughts, feelings and dreams of the protagonists (Kelly 41), and was flexible in its ability to move with the dramatic action (Kelly 59). While film had been used before in drama, it did not accompany it, but rather was self-contained ${ }^{5}$. Christophe Colomb is at times an examination of the explorer's conscience, and for this both the visible and invisible needed to be made manifest. As Éric Touya de Marenne writes, Claudel believed that "le monde véritable était à découvrir au-delà de la logique où nous l'avions enfermé" (Touya de Marenne 76), and so it is what we would call today "out of the box thinking" or breaking out of the "enfermé" which the author attempts to 


\section{Claudel's Call in America for a new form of Drama and Music}

express. Claudel also used different levels on the stage to represent various spiritual states (Kelly 40).

As to music, Darius Milhaud (1892-1974), his collaborator, showed an equally strong desire to innovate and to reach across national traditions. "Milhaud...was notorious in his search for novelty" (Kelly 83 ). He also rejected any single aesthetic tradition, as too free a spirit to agree to such constraints. (Kelly 43). His use of polytonality, musical eclecticism and the influence of jazz encountered while in Brazil as Claudel's secretary has already been commented upon ${ }^{6}$. Milhaud sought freedom in his music through modality which opened up more possibilities for experimentation and allowed him to look both backwards and forwards (Kelly 108). That same penchant and gift for consolidating diverse and even dissonant elements is precisely what enabled Claudel to entrust his words and stage directions to him, as he commented:
Musicalement, il me semble que le drame est fait pour vous par tous les éléments violemment disparates, con- trastés et disloqués que vous avez l'art de réunir, de pétrir et de faire marcher ensemble. (Claudel 1961, 69)

This is the same quality which Claudel admired in the artist Jean Charlot who illustrated his book, "l'art de présenter aux yeux différentes choses ensemble" (Claudel 1965, 296). For his part, it was the interior rhythm of Claudel's prose that attracted Milhaud (Kelly 3). Tellingly, Milhaud gives the character of the cook in the opera greater musical flexibility, since his role is complex. Much of the opera's success is attributable to its rhythm, instrumentation and harmony (Kelly 110), as well as to the perseverance and enthusiasm of both artists. Milhaud stated, “Tout ce qu'il me dit sur Christophe Colomb est terriblement exciting" (Claudel 1961, 135) and Claudel had written to Milhaud "Je suis enchanté et très excité de ce que vous me dites de Ch. Colomb" (Claudel 1961, 97).

Thus, rather than seeing other genres as competitors or potential threats, Claudel was quick to adapt them, especially when seeking a moving décor, as a way of transcending rigidity; 


\section{Kathleen Madigan}

whenever his theatre came up against a wall, that is, an "impossible image", Claudel resorted to film. As Autrand eloquently states, "Le cinéma devient la musique de la lumière... Il permet dans le spectacle le flou, le mouvement, la pensée" (Autrand 316). In spite of their immobility, the plastic arts were also movement for Claudel, or rather pending movement (Autrand 312).

In related arts, Claudel incorporated what he had learned in Germany and Japan about gesture and movement (Kelly 102). Gesture was so important to Claudel because he thought of it as a ritualistic enactment of thought, and for this reason often gave detailed stage instructions (Kelly 38). What he admired in the dancer Nijinsky, for instance, was that ability to soar over walls, "Il s'agit d'échapper au sol" (Claudel 1965, 162), the victory of ascension over gravity, "la victoire de la respiration sur le poids" (Claudel 1965, 368). In terms of music, Claudel was to speak of that of Arthur Honegger as well as an "appel à la liberté et à l'essor" (Claudel 1965, 161). He reached out to many forms of art, including music, drawing, dance and film, to help his drama to take wing.

On a personal level, Claudel engaged in lively discussion with colleagues from different artistic, national and religious backgrounds. On the one hand, particularly strong attempts to win over others such as Milhaud to his points of view may be noticed, or on the other, what has been characterized as erasure of difference in religions, mythologies and cults which are not Catholic and therefore merge into the Other (Mukherjee 36). To be fair, we may keep in mind that Claudel lived before the interfaith movement and was not above being influenced in turn, even if this was not emphasized. Though Jean Charlot, for instance, felt that the religion of his Mexican ancestors had not been taken seriously by Claudel, John Charlot writes that in minor texts, he [Claudel] revealed that through Jean Charlot..." he had been imbued with some understanding of and appreciation for Aztec culture" (Charlot 72). In some ways Claudel was ahead of his times since in his version, Columbus is confronted with the sufferings of the natives, slaves and his abandoned family (Kelly 55). 


\section{Claudel's Call in America for a new form of Drama and Music}

Differences in religion, in any case, never stop stopped Milhaud and Claudel from deep engagement in discussing their theories over a long period of collaboration (Kelly 109). And a close reading of their correspondence reveals not only deep respect and abiding affection, despite Claudel's apparent preference for work with Honegger later, but a spontaneous effort on Claudel's part to celebrate with his Jewish friend the beauty of that spirituality as he discovers it; for instance, with regard to a work titled Quand Israël aime Dieu, he comments:

Elle contient des études sur les mystiques juifs du XVIII siècle, dits Hassidim. Il y a là des choses splendides, dignes des plus grands mystiques... Il est consolant de penser que dans toutes les religions se trouvent des âmes si hautes, pareilles à des séraphims dont les ailes se rejoignent par les extrémités les plus hautes.

Je vous serre affectueusement la main. (Claudel 1961, 193)

In this thought, that in all religions one finds souls so high, similar to the seraphims, the wings of which meet at the highest extremities, Claudel surely rises above any walls purportedly constricting his vision. One also finds towards the end of his correspondence a certain refusal to take himself too seriously, even as he becomes more involved in his commentaries on Scripture. He writes to Milhaud when France was liberated in 1945 that he was on the point of taking a plane for America to see his family, but that "ce saut dans la stratosphère n'est pas précisément à recommender pour un homme de mon âge" (Claudel 1961, 251). A different kind of leap is described by Milhaud in his "Adieu" to Claudel after his death. Milhaud stated "ce grand catholique est à présent avec Dieu qu'il a tant aimé, tant servi" (Claudel 1961, 349). Louis Chaigne comments "every soul which rises, raises the world with it" (Chaigne 275). The Claudel-Milhaud correspondence, in spite of some remarks by Claudel which might be considered particularly strong today ${ }^{7}$ apparently buffered by 


\section{Kathleen Madigan}

Milhaud's indulgence and the consistency of their deep and genuine mutual respect, is nothing if not uplifting. ${ }^{8}$

It is the author's broadness of outlook which Chaigne calls almost unmatched at the time of his death, due to his extensive travels and understanding of foreign cultures and literatures (Chaigne 1). Claudel's call "not to accept walls" is ultimately moving not only in terms of his art poétique and almost Herculean efforts to create theatre beyond theatre, in all its international, interdisciplinary and indeed otherworldly scope, but also because of his personal struggle to rise above the inner surfaces of the cathedral of his personal vision, over which he himself at times was consoled to catch a glimpse of the wings of more than one tradition hovering.

\section{Notes}

1 Note \#1 states that the date was February 19 or 20, 1930.

2 See "L'Adieu de Darius Milhaud" (Claudel 1961, 350): "Honegger...a admirablement décrit dans son livre Je suis compositeur, comment Claudel savait suggérer à son musicien l'atmosphère requise pour sa partition."

3 Milhaud felt that Debussy's followers were leading French music to an impasse (Kelly 2).

4 "Pendant plusieurs semaines, j'ai traîné ce projet avec dégoût, malgré les insistances de Sert. Finalement j'ai vu Reinhardt à qui j'ai exposé mes idées sans beaucoup de conviction... Mais alors est survenu un coup de théâtre. Une des idées qui m'étaient venues dans la conversation a pris feu, j'ai vu mon chemin tout à coup et j'ai écrit dans l'enthousiasme...la pièce presque toute entière" (Claudel 1961, 78).

5 Reference here is to the film "Entr'acte" by René Clair in Satie and Picabia's "Relâche" in 1924 (Kelly 60).

6 The superimposition of different modes and tonal centres results in polytonality (Kelly 79). In addition to the new timbres to which it exposed him, the contrapuntal freedom resulting from the constant use of syncopation in the melody of jazz fascinated Milhaud (Kelly 86 and 91). 
7 One of the passages sometimes cited in this regard is part of a letter written from Claudel to Milhaud ("Cher ami") on November 13, 1928. Even here, one senses trust and affection, as disconcerting as this paragraph may be to some: "Quel dommage que vous ne soyez pas catholique! Nous ferions de grandes choses ensemble. Si je continue à écrire, j'aurai de plus en plus besoin de la musique. Et quant à vous, la grande musique dramatique et religieuse est votre véritable voie. C'est un terrain presque vierge. Quel dommage que je ne puisse vous faire entrer dans l'édifice dont vous séparent tant de fossés vaseux et de murailles rebutantes! Du dedans tout prend un nouvel aspect" (Claudel 1961, 108). On April 27, 1929, Darius Milhaud writes to Claudel ("Mon cher ami") about visiting the tomb of Columbus in the cathedral of Seville ("admirable") and seeing his manuscripts in the attached library (Claudel 1961, 113). Claudel also makes efforts to connect with Milhaud, writing in a postscript to a letter dated September 25, 1929 that it might interest him to know that the first during the Columbus expedition to see land and to step onto land were Jews, as well as the one who kept accounts of expedition costs (Claudel 1961, 121).

8 Claudel certainly recognized mutual influence between himself and Milhaud; in a letter dated May 29, 1930, he wrote, "il y a une si grande habitude et une si grande pénétration réciproque que nous travaillons ensemble et que vous réagissez sur moi aussi bien que moi sur vous" (Claudel 1961, 144).

\section{Works Cited}

Autrand, Michel. "Naissance du cinéma dans le théâtre de Paul Claudel" Reque-Société d'histoire du théâtre 4 (1995): 311-318.

Chaigne, Louis. Paul Claudel: The Man and the Mystic. Trans. Pierre de Fontnouvelle. New York: Appleton-Century-Crofts, Inc., 1961.

Charlot, John. "Jean Charlot as Paul Claudel's Ixtlilxochitl" The Journal of Intercultural Studies $17 \& 18$ (1990-1991): 64-74.

Claudel, Paul "On Drama and Music" in Le Livre de Christophe Colomb (Préface 9-37). Paris: Gallimard, 1935. Also in Euvres en Prose (see below) 143-155.

Claudel, Paul et Darius Milhaud. Correspondance Paul Claudel-Darius Milhaud 1912-1953. Eds. Henri Hoppenot et Jacques Petit. Cahiers Paul Claudel 3. Paris: Gallimard, 1961. 


\section{Kathleen Madigan}

Claudel, Paul. Oeuvres en Prose. Eds. Jacques Petit et Charles Galpérine. Paris: Éditions Gallimard, 1965.

Kelly, Barbara Lucy. The Collaboration between Darius Milhaud and Paul Claudel on Christophe Colomb. Thesis (M.A.) University of Illinois at Urbana-Champaign, 1933.

Mukherjee, Madhuri. "Claudel's Poetic Conversions" Cahiers Paul Claudel I (Jan. 2003): 23-39.

Touya de Marenne, Éric. "Littérature et transculture: Claudel, Milhaud et l'art de la polyphonie" Paul Claudel Papers. V (Dec. 2007): $73-77$. 